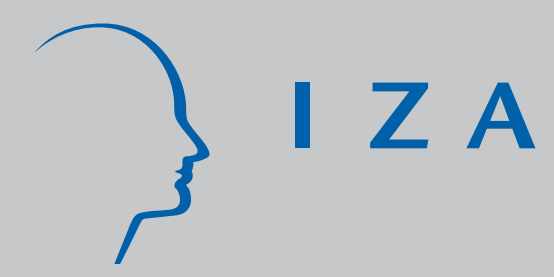

IZA DP No. 2432

Income Support Policies for Part-Time Workers: A Stepping-Stone to Regular J obs? An Application to Young Long-Term Unemployed Women in Belgium

Bart Cockx

Stéphane Robin

Christian Goebel

November 2006 


\title{
Income Support Policies for Part-Time Workers: A Stepping-Stone to Regular Jobs? An Application to Young Long-Term Unemployed Women in Belgium
}

\author{
Bart Cockx \\ Université catholique de Louvain, \\ CESifo and IZA Bonn \\ Stéphane Robin \\ BETA-Cereq, University of Strasbourg I, PEGE \\ and Université catholique de Louvain \\ Christian Goebel \\ Université catholique de Louvain and ZEW
}

Discussion Paper No. 2432

November 2006

\author{
IZA \\ P.O. Box 7240 \\ 53072 Bonn \\ Germany \\ Phone: $+49-228-3894-0$ \\ Fax: +49-228-3894-180 \\ E-mail: iza@iza.org
}

\begin{abstract}
Any opinions expressed here are those of the author(s) and not those of the institute. Research disseminated by IZA may include views on policy, but the institute itself takes no institutional policy positions.
\end{abstract}

The Institute for the Study of Labor (IZA) in Bonn is a local and virtual international research center and a place of communication between science, politics and business. IZA is an independent nonprofit company supported by Deutsche Post World Net. The center is associated with the University of Bonn and offers a stimulating research environment through its research networks, research support, and visitors and doctoral programs. IZA engages in (i) original and internationally competitive research in all fields of labor economics, (ii) development of policy concepts, and (iii) dissemination of research results and concepts to the interested public.

IZA Discussion Papers often represent preliminary work and are circulated to encourage discussion. Citation of such a paper should account for its provisional character. A revised version may be available directly from the author. 
IZA Discussion Paper No. 2432

November 2006

\title{
ABSTRACT
}

\section{Income Support Policies for Part-Time Workers: A Stepping-Stone to Regular Jobs? An Application to Young Long-Term Unemployed Women in Belgium*}

\begin{abstract}
We verify whether an income support policy for part-time workers in Belgium increases the transition from unemployment to non-subsidised, "regular" employment. Using a sample of 8630 long-term unemployed young women, whose labour market history is observed from 1998 to 2001, we implement the "timing of events" approach proposed by Abbring and Van den Berg (2003) to control for selection effects. Our results suggest that the policy has a significantly positive effect on the transition to non-subsidised employment when one does not control for unobserved heterogeneity. This effect remains positive, but becomes insignificant, when one corrects for selection on unobservable characteristics.
\end{abstract}

JEL Classification: J64, J68, C41

Keywords: active labour market policies, evaluation, mixed proportional hazard models

Corresponding author:

Bart Cockx

Department of Economics

Université catholique de Louvain

Place Montesquieu 3

B-1348 Louvain-la-Neuve

Belgium

Email: cockx@ires.ucl.ac.be

\footnotetext{
" This research was part of the "Social cohesion" framework programme (Contract SO/10/039); the authors gratefully acknowledge financial support from the services of the Belgian Prime Minister for Sciences, Technical and Cultural Affairs (SSTC).
} 
The high and persistent unemployment rate encountered in many European countries has been a major concern of policy makers for over twenty-five years. Since the Amsterdam Treatise was adopted (in June 1997), the European Union (EU) explicitly recommends the implementation of "active" labour market policies (hereafter ALMP): unemployment insurance systems should be reformed to enhance employability and to favour the transition of unemployed workers towards employment. One of these ALMP is income support granted to low-wage and/or part-time workers. Income support has been provided in several European countries (including Belgium, France, and the UK) and will be the focus of our analysis.

In Belgium, since 1980, unemployed workers who have accepted a part-time job and who are still looking for full-time employment are allowed to keep a fraction of their unemployment benefits. In 1993, this led to the creation of a new legal status: that of "parttime worker with entitlement (to unemployment benefits)". These part-time workers are granted an income premium, known as AGR (Allocation Garantie de Revenu). Theoretically, it is unclear whether AGR is a stepping-stone to regular employment. On the one hand, the labour market experience that a worker may acquire during the course of this ALMP could increase his/her employability. On the other hand, because of its design, this policy may create a "part-time employment trap": indeed, the income support decreases in direct proportion to an increase in the worker's wage. The objective of the present study is to determine which of the two effects actually prevails.

Our evaluation concerns only a subset of the eligible population. First of all, men are not taken into account: the small number of male recipients would make the econometric analysis awkward at best. Second, the Belgian government sponsored this study in order to identify, among existing ALMP, those that are most likely to help disadvantaged youth out of unemployment. We therefore retained, for our analysis, a population of 8630 young long-term unemployed women without any labour market experience. They were selected nine month after graduating (at various levels of education), at the moment they were entitled to unemployment benefits. The choice of this population was dictated by a concern for alleviating the serious problems met by young people (and especially young women) on the Belgian labour market.

The paper is organized as follows. A first section describes the institutional context of the Belgian unemployment insurance system and the AGR. A second section surveys the empirical literature dedicated to the evaluation of income-support policies. The third and fourth sections respectively present our data and econometric model. The results of our analysis are presented in Section 5. Conclusions are given in a final section.

\section{Institutional context.}

In Belgium, eligibility to unemployment insurance corresponds to two different labour market situations. On the one hand, as in many countries, when a worker loses her job ${ }^{4}$, she is entitled to unemployment benefits, provided that she contributed to the unemployment insurance system while she was working. In that case, eligibility depends on the length of the previous employment spell, and, legally, this length increases with age ${ }^{5}$. On the other hand, the Belgian system is very specific, in the sense that unemployed youth (below 30) may obtain entitlement to unemployment benefits, provided: (i) that they were registered in the

\footnotetext{
${ }^{4}$ In the rest of the text, we use "she" instead of "he/she" and her instead of "his/her".

${ }^{5}$ Special conditions apply to workers having followed courses in "second chance" education, in training centres for the self-employed, or in part-time vocational education.
} 
third year ${ }^{6}$ of secondary education or at a higher level and (ii) that they did not drop out before the end of the school year (on June, $30^{\text {th }}$ ). They do not have to pass the exams ${ }^{7}$.

Young job seekers who have just left the education system, have to go through a 'waiting period' before being formally entitled to unemployment benefits. The length of this waiting period depends on age: 6 months for job seekers below 18, 9 months for job seekers aged 18-25, and 12 month for those aged 19-26. Our analysis is concerned with a sample of 18 to 25 year-old women who, at the end of the waiting period, are still looking for a job. Their date of entry into the database corresponds to their date of entry in 'insured' unemployment, i.e. to the date when they first receive unemployment benefits ${ }^{8}$.

The level of unemployment benefits in Belgium depends on the last wage (for those who were previously employed), the length of the unemployment spell, on family status, and on age. For unemployed youth without labour market experience, only family status and/or age are taken into account. For instance, in December 2005, monthly unemployment benefits for the 18-25 year old were equal to: 872 euros for cohabitants with children, 361 euros for cohabitants without children (if both cohabitants are unemployed), 339 euros for cohabitants without children. For singles, monthly unemployment benefits depend only on age: 381 euros if aged 18-20, 626 euros if aged 21-24, and 620 euros for ages 25 and up. Different from any other OECD country, these benefits are provided without any time limit.

The existence of unemployment benefits for youth without labour market experience is a unique institutional arrangement. It is justified (from a political point of view) by the fact that youth unemployment is extremely high in Belgium: in 2003, the unemployment rate of the 15-24 year old was equal to $21 \%$, whereas the average unemployment rate in Belgium was equal to $8 \%$ only (European Commission, 2004). In the Walloon region and in Brussels, youth unemployment was even higher, with rates rising up to $32 \%$ and $35 \%$ respectively (Eurostat, 2004). In Flanders, however, the unemployment rate of the young was a little bit lower (15.5\%), but still higher than the average.

The AGR is a premium granted to full-time job seekers who accept a part-time job (the duration of which should be less than 4/5 of a full-time job). This premium cannot be granted if the monthly wage of the part-time worker is higher than minimum wage (equal, in December 2005, to 1,234€/month for full-time workers aged 21 and up). Moreover, in order to receive AGR, the part-time worker should keep on searching for a full-time job. Therefore, the AGR can be considered as an ALMP designed to accelerate the transition to full-time employment. If a worker who receives AGR loses his part-time job, he will be considered as unemployed and will again be entitled to full-time unemployment benefits.

The level of the AGR is calculated as follows. One takes the level of benefits for a full-time unemployed worker. One adds a bonus, which depends on family status (in June 2004, this bonus was equal to 154 euros for cohabitants with children, 123 euros for singles and 92 euros for cohabitants without children). The final amount of AGR is then computed by deducing from that sum the wage associated to the part-time job. In other words, the AGR is

\footnotetext{
${ }^{6}$ Students outside vocational/ technical training or arts must be registered in the fourth year or higher.

${ }^{7}$ Consequently, for some the highest attained degree may be primary education (after 6 years of schooling): the next level, lower secondary, is only attained after successfully completing three years of secondary education. This explains why in Table 1 the fraction of workers with a primary school education level is strictly positive.

${ }^{8}$ Our data do not allow us to observe individuals before the end of the waiting period, which means they are not observed at their entry in the labour market, but at their entry in 'insured' unemployment.
} 
computed using the formula: "AGR = benefits + bonus - wage from part-time job". This subsidy is awarded for an indefinite time period, as long as eligibility criteria are satisfied.

Cohabitants with children are more represented among actual recipients of AGR, probably because their income bonus is more generous. In 1997, they represented $64 \%$ of young AGR recipients (i.e. those without labour market experience who became eligible at the end of the aforementioned "waiting period"). Singles and cohabitants without children represented only $16 \%$ and $20 \%$ (respectively) of that same category of AGR recipients.

Although the AGR aims at increasing workers' employability and is supposed to serve as a stepping-stone to full employment, this policy may actually replace the "unemployment trap" by a "precarious employment trap" (Degreef, 2000). Indeed, the AGR imposes a 100\% implicit marginal tax rate to any wage increase: for each euro added to the part-time wage, one euro is deduced from the bonus. This policy has been revised in July 2005, in order to correct this anomaly. Our study, however, evaluate the AGR policy before this reform was implemented.

\section{Survey of the literature}

Different types of income-support policies for low-wage workers have been implemented in various European countries (e.g., "employment premium" in France, "Working Families Tax Credit" in the UK). Several studies suggest that these policies accelerate the transition from unemployment to employment (e.g., Meyer, 1995; Cahuc, 2002; Blundell and Hoynes, 2004; Francesconi and van der Klaauw, 2004 ; Eissa and Hoynes, 2005). This conclusion does not depend on whether the support is awarded to the head of household or is granted to individuals (which is the case of the AGR). However, most of these studies concern the USA and the UK, where the minimum wage is much lower than in continental Europe. In continental European countries, the level of employment may be more sensitive to labour costs than to labour supply incentives (Cahuc, 2002). Moreover, the aforementioned studies do not specifically focus on part-time workers, but, more generally, on low-wage workers.

McCall $(1996,1997)$ has evaluated a system of income support for part-time workers in Canada. In this country, an unemployed worker who accepts a part-time job keeps his weekly allowance as long as his weekly wage remains below $25 \%$ of this allowance. Beyond that threshold, one (Canadian) dollar is deduced from the allowance for each additional dollar gained through part-time work. Consistent with theory, the author finds that a $50 \%$ increase in this income support tends to increase the probability of getting a part-time job (by $2 \%$ to $3 \%$ ) and to decrease unemployment duration (by 2.5 to 6.2 days). These effects, however, are relatively small.

The aforementioned studies do not specify whether income supports accelerate the transition to "regular" employment (i.e., non-subsidised, full-time employment). This depends on the rate of progression of the earnings (a function of the hourly wage and/or working time): if earnings increase sufficiently, the amount of the subsidy drops to zero. Theoretically, an income support such as AGR may accelerate as well as decelerate this transition. Arguments in favour of acceleration are as follows. A job-seeker who accepts a subsidised, part-time job signals his motivation and attachment to the labour market to employers (Gerfin et al., 2002). In addition, according to human capital theory, labour market experience and onthe-job training should lead to an increase in productivity and, in fine, in wages. 
However, recent empirical studies have shown that returns to labour market experience are lower for low-skill workers ${ }^{9}$. Moreover, in the case of AGR, the $100 \%$ implicit marginal rate of taxation reinforces this "locking-in" in low wage subsidised employment (Calmfors, 1994 ; Van Ours, 2002). Finally, the aforementioned signalling argument may also slow down the transition to a regular job. For instance, employers may believe (righteously or not) that workers who accept part-time jobs do not wish to work full-time. In that case, accepting a part-time job sends a negative signal to employers ${ }^{10}$.

Many researchers (e.g., Booth et al., 2002; Zijl et al., 2004; Autor et al., 2005; D'Addio and Rosholm, 2005; Gagliarducci, 2005; Kvasnicka, 2005; Larssen et al., 2005) have studied the impact of temporary jobs and employment for temporary work agencies on the transition to regular, permanent employment. These studies report mixed results. To our knowledge, few researchers have studied the impact of part-time (subsidised) work on labour market reintegration. Buddelmeyer et al. (1995) find that in the European Union, less than 5\% of unemployed workers use part-time work as a stepping-stone to full-time employment. Blank (1998) shows that in the USA, men and women who work part-time tend to remain in that situation for a long period of time, and experience few transitions to full-time employment. However, these studies are primarily descriptive, and do not allow determining whether accepting a part-time job accelerates the transition to a full-time job. Farber (1999) suggests that in the USA, part-time work may be a phase in the transition from unemployment to full-time employment, but his analysis remains inconclusive.

Granier and Joutard (1999) is the only study that addresses the same issue as we do here, using a similar methodology. They estimate the impact on the transition to regular employment of an income-support policy for part-time workers in France. This policy allows a (full-time) job seeker working less than 136 hours a month (and receiving less than $70 \%$ of her previous wage) to cumulate his labour income and unemployment benefits. The scheme is designed to prolong the worker's entitlement to the allowance proportional to his working time.

The French scheme provides more incentives to transit to regular employment then the Belgian AGR. First, the implicit withdrawal rate of the subsidy is equal to the replacement rate, and not to $100 \%$ as in Belgium. Second, since in France the duration of the entitlement to the subsidy coincides with the duration of the entitlement to the benefits, the worker who doesn't find a regular job before the subsidy expires, will not be entitled to any other allowance of the unemployment insurance system. This contrasts sharply with the Belgian system in which the entitlement to both the subsidy and the benefits is indefinite.

Granier and Joutard (1999) conclude that this policy increases the transition to regular employment, especially close to the moment at which unemployment benefits expire. This transition is only delayed for long-term (more than 18 months) unemployed women. It is not clear, however, whether this acceleration is caused by income support per se, or whether it results from the existence of a time limit on the entitlement to the benefits.

\footnotetext{
9 Cf. Card and Robins (1999), Gladden et Taber (2000), Meghir et Whitehouse (1996), Dustmann and Meghir (2001), Card et Hyslop (2005). In Grogger (2005), though, returns to experience are not significantly different among low-skill and high-skill workers.

${ }^{10}$ See Ma and Weiss (1993) and McCormick (1990) for a theoretical foundation of that argument. This argument is referred to by Burtless (1985) and Bonnal et al. $(1994$; 1997) in their evaluation studies. See Dubin and Rivers (1993) for a critique of that point of view.
} 


\section{Data}

Our study uses administrative data centralised in a "Labour Market Data warehouse". This database is the result of a joint effort from the central databank of the Belgian Social Security (BCSS) and from various social security institutions. The Data warehouse gathers individual and longitudinal information on the labour market histories of Belgian workers. It contains quarterly information on unemployment, employment (including self-employment) and inactivity spells (identified by non-presence in any of the other spells). It allows to identify most ALMP including subsidised employment such as AGR.

The sample has been selected according to three criteria. We retain: (1) women aged 18-25, (2) who, in 1998, were for the first time entitled to unemployment benefits, and (3) who did not have any labour market experience during the 9 months waiting period following the end of their initial schooling. This leaves us with a sample of 8630 disadvantaged women. The observation period stops at the end of year 2001.

Table 1 reports summary statistics for the explanatory variables. We distinguish three groups: (1) AGR recipients or the "treated group", (2) individuals who experience a direct transition from unemployment to full-time regular employment (and constitute our "control group"), and (3) censored individuals. This last group includes young women who remained unemployed over the whole observation period (1998-2001). We also include in that group women who experience a transition to inactivity (including education) or to other ALMP (such as training or temporarily subsidised employment). These transitions are ignored in order to keep the econometric model tractable, and to avoid that participation to other ALMP contaminates the control group. We observe 175 AGR recipients, 3458 women in the control group, and 4997 censored individuals.

We give a brief synthetic view of the observed differences between groups, by comparing first the censored group and the control group, and then the treated group and the control group. The censored group gathers mostly inactive women, and women with long unemployment spells. Belgians are less represented in the censored than in the control group ( $85 \%$ versus $91 \%$ ), while non-EU foreigners are slightly more represented ( $9 \%$ versus $4 \%$ ). Low-skill women are also more represented in the censored than in the control group: $39 \%$ in the former (versus $18 \%$ only in the latter) have less than 12 years of schooling. The censored and control groups also differ with regard to family status: in the former, $14 \%$ of the women have children younger than 3, whereas in the latter, this percentage is equal to $5 \%$ only. Moreover, only $67 \%$ of the women in the censored group live with their parents (versus $80 \%$ in the control group). This suggests that the control group may face more difficulties in finding childcare during their working hours. Finally, women in the censored group live in sub-regions ${ }^{11}$ where the unemployment rate ${ }^{12}$ is slightly higher than average. They are less present, though, in the Walloon region than in Flanders or in Brussels; this is somehow paradoxical, since unemployment tend to be higher than average in the Walloon region.

\section{TABLE 1 ABOUT HERE}

\footnotetext{
${ }^{11}$ The Belgian territory is divided in 30 sub-regions.

12 This statistic is measured by the ONEM (Belgian Unemployment Office) as a percentage of the population insured against the risk of unemployment. The retained denominator is smaller than the actual labour force. Consequently, it blows the unemployment rate up.
} 
Women in the treated group (i.e. AGR recipients) are less educated: $31 \%$ have 12 years of schooling or less (versus $18 \%$ only in the control group). Moreover, women in the treated group, just like those in the censored group, live less at their parents' (64\% versus $80 \%$ in the control group), tend to have more young children (12\% versus $5 \%$ in the control group) and live in areas where the unemployment rate is higher than average. The treated group therefore seems to have a lower employability, compared to the control group. A single indicator contradicts that observation: AGR recipients are more represented in Flanders (68\% versus $60 \%$ in the control group), a region where the unemployment rate is lower.

\section{Econometric modelling}

In our study, as in any evaluation study, we face the "selection bias" problem. To estimate the impact of AGR on the rate of transition to employment, we have to compare the histories of AGR recipients (treated group) to those of non-recipients (control group). By doing so, we may capture not only the effect of the AGR per se, but also the effect of unobserved differences (in terms of employability, for instance) between both groups. To solve this problem, we control for differences between the treated and control groups on the basis of both observed and unobserved individual characteristics. To control for unobserved characteristics (unobserved heterogeneity) we rely on the "timing of events" method. This method exploits the fact that unobserved heterogeneity affects the transition to regular employment throughout the unemployment spell, whereas the treatment (AGR in this study) may only influence this transition from the moment at which the treatment occurs. By this "discontinuity", one can identify the treatment effect from the selection effect without imposing any "exclusion restrictions" on the observed explanatory variables. Abbring and Van den Berg $(2003,2004)$ indeed showed that non-parametric identification is ensured provided that:

(1) Agents do not anticipate this starting date. This is a reasonable assumption here, since it is difficult for an unemployed worker to anticipate if and when she will receive a part-time job offer.

(2) The econometrician has precise information concerning the timing of transitions;

(3) Observed and unobserved individual characteristics influence the rates of transitions (to subsidised employment and to regular employment) proportionally.

(4) There are no unobserved random shocks that are correlated with the timing of the treatment; we try to avoid this by conditioning on a time-varying indicator of the local unemployment rate.

If these conditions are satisfied, estimating a bivariate Mixed Proportional Hazard (MPH) model corrects for the selection bias.

The above-mentioned second condition is not completely satisfied in this application, since we only have quarterly information. However, Gaure et al. (2005) have shown, using an extensive Monte Carlo analysis, that Abbring and Van den Berg (2003)'s method is extremely reliable, even for time-grouped data. To apply this method, it is sufficient that the assumption of proportionality be satisfied and that the unobserved heterogeneity distribution be flexible.

\subsection{The bivariate MPH model}

We estimate a competing-risks duration model in which transition rates are proportional to observed and unobserved destination specific $(e=$ employment; $p=$ programme $(A G R)$ participation) explanatory variables, denoted $\mathrm{X}$ and $\mathrm{V}=\left(v_{p}, v_{e}\right)$ respectively. Variables $\mathrm{X}$ and $\mathrm{V}$ are independently distributed. In this model, transitions to 
AGR on the one hand and to regular employment on the other are represented by two latent continuous durations, respectively $T_{p}$ and $T_{e}$. More generally, we will use index $p$ for parameters and variables related to the AGR policy, and index $e$ for parameters and variables related to regular employment.

The distribution of $\left(T_{p}, T_{e}\right)$ conditional on $\left(X, v_{p}, v_{e}\right)$ is characterised by hazard functions. If we assume that these are of the MPH form: ${ }^{13}$

$$
\begin{aligned}
& \ln \theta_{p}\left(t \mid X, v_{p}, v_{e}\right)=\ln \lambda_{p}(t)+X^{\prime} \beta_{p}+v_{p} \\
& \ln \theta_{e}\left(t \mid t_{p}, X, v_{p}, v_{e}\right)=\ln \lambda_{e}(t)+X^{\prime} \beta_{e}+\delta . I\left(t>t_{p}\right)+v_{e}
\end{aligned}
$$

where $\lambda_{p}(t)$ and $\lambda_{e}(t)$ represent the baseline hazard for transitions to AGR and to regular employment respectively, and where $I($.$) is an indicator function, equal to 1$ if the argument is true, and to 0 otherwise. Consequently, $\delta$ measure the impact of AGR on the transition to fulltime (regular) employment. We impose this effect to be independent of other explanatory variables. Abbring and Van den Berg (2003) show that the interactions of this effect with other explanatory variables can be identified. In our study, however, the small number of AGR recipients does not allow for such a flexible specification.

In our database, durations are not measured in continuous time, but in quarters. This leads us to specify the baseline hazard as piecewise constant. The time axis is divided into $m$ intervals $\mathrm{I}_{l}=\left[\tau_{l}, \tau_{l+1}\right.$ [, where $l=1,2, \ldots, m$ and $\tau_{1}<\tau_{2}<\ldots<\tau_{\mathrm{m}}$, with $\tau_{1}=0$ and $\tau_{\mathrm{m}+1}=\infty$. The baseline hazard can then be written:

$$
\ln \lambda_{p}(t)=\sum_{l=1}^{m} \alpha_{l}^{p} d_{l}^{p}
$$

$$
\ln \lambda_{e}(t)=\sum_{l=1}^{m} \alpha_{l}^{e} d_{l}^{e}
$$

where the $\alpha_{l}$ 's are parameters to be estimated for interval $l$, and where $d^{p}{ }_{l}\left(d^{e}{ }_{l}\right)$ is an indicator equal to 1 if a transition to AGR (full-time employment) occurs during interval $\mathrm{I}_{l}$ and to 0 otherwise.

The model is estimated by Maximum Likelihood using the BFGS algorithm. We distinguish three types of contributions to the likelihood, which depend on individual labour market histories: $l_{u}$ for right-censored individuals at time $t_{k}{ }^{14} ; l_{p}$ for AGR recipients between $t_{k-1}$ and $t_{k} ; l_{e}$ for individuals experiencing a transition to regular employment between $t_{k-1}$ and $t_{k}$.

\footnotetext{
${ }^{13}$ One of our explanatory variables is time varying, but, for the sake of simplicity, we do not condition X on time in Equation (1). Our time-varying variable is the rate of unemployment in the sub-region of residence. We consider its evolution, starting at the time when the individual becomes entitled to unemployment benefits. This variable controls for seasonality and business cycle effects in local labour markets.

${ }^{14}$ Women experiencing a transition to inactivity or to another ALMP are censored at the end of the quarter preceding this transition. Women who are unemployed during the whole observation period are censored at the end of year 2001.
} 
These contributions are written:

$$
\begin{aligned}
& l_{u}(V)=\operatorname{Prob}\left(T_{p}>t_{k}, T_{e}>t_{k} \mid X, V\right)=S_{u}\left(t_{k} \mid X, v_{e}, v_{p}\right) \\
& l_{p}(V)=\operatorname{Prob}\left(t_{k-1}<T_{p} \leq t_{k} \mid X, V\right)=\frac{\theta_{p}\left(t_{k} \mid X, v_{p}\right)}{\theta_{p}\left(t_{k} \mid X, v_{p}\right)+\theta_{e}\left(t_{k} \mid X, v_{e}\right)}\left[S_{u}\left(t_{k-1} \mid X, v_{e}, v_{p}\right)-S_{u}\left(t_{k} \mid X, v_{e}, v_{p}\right)\right] \\
& l_{e}(V)=\operatorname{Prob}\left(t_{k-1}<T_{e} \leq t_{k} \mid X, V\right)=\frac{\theta_{e}\left(t_{k} \mid X, v_{e}\right)}{\theta_{p}\left(t_{k} \mid X, v_{p}\right)+\theta_{e}\left(t_{k} \mid X, v_{e}\right)}\left[S_{u}\left(t_{k-1} \mid X, v_{e}, v_{p}\right)-S_{u}\left(t_{k} \mid X, v_{e}, v_{p}\right)\right]
\end{aligned}
$$

where $S_{u}$ is the survival function in the initial state (unemployment $u$ ).

The survival rate in unemployment at time $t_{k}$ (i.e. the probability of still being unemployed at time $t_{k}$ ) is denoted $S_{u}\left(t_{k} \mid\right.$.) and can be expressed in terms of the hazard function as in (4):

$$
S_{u}\left(t_{k} \mid X, v_{e}, v_{p}\right)=\exp \left[-\sum_{j=1}^{k}\left[\theta_{p}\left(t_{j} \mid X, v_{p}\right)+\theta_{e}\left(t_{j} \mid X, v_{e}\right)\right]\right]
$$

The log-likelihood can then be written as the sum of individual contributions:

$$
\mathcal{L}=\sum_{i=1}^{N}\left\{J_{u i} \ln \left[l_{u i}(V)\right]+J_{p i} \ln \left[l_{p i}(V)\right]+J_{e i} \ln \left[l_{e i}(V)\right]\right\}
$$

where $J_{m i}$ is equal to 1 if $l_{m i}$ is the contribution of individual $i$ to the likelihood $(m=u, p, e)$, and to 0 otherwise.

In our application, the model is estimated three times: first without controlling for unobserved heterogeneity - which is equivalent to setting $V=(0,0)$ - and twice with a different form of the unobserved heterogeneity distribution. In these last two cases, we integrate the contributions to the likelihood with respect to $\mathrm{V}$ in order to get the unconditional contributions:

$$
l_{m}=\int_{V} 1_{\mathrm{m}}(V) d G(V)
$$

where $\mathrm{G}$ is the joint distribution function of the unobserved heterogeneity terms. We can control for selection on unobservables, as long the specification of the heterogeneity distribution allows for a correlation between $v_{p}$ et $v_{e}$.

\subsection{Specification of the unobserved heterogeneity distribution}

Gaure et al. (2005) show that, in order to get unbiased estimates, one must correctly specify the heterogeneity distribution. In order to do so, we implement a non-parametric approximation of the heterogeneity distribution using a finite number of 'points of support' (Lindsay, 1983; Heckman et Singer, 1984). In order to find the 'correct' specification, we follow Gaure et al. (2005)'s approach by gradually introducing more points of support, until the likelihood stops increasing. 
First of all, we impose a one-factor loading specification for $\mathrm{G}$, in which the factor consists in two points of support. This specification is widely used in the literature. Its main drawback is that it strongly constrains the correlation between unobserved heterogeneity terms: only perfect correlation or no correlation are allowed (Van den Berg, 2001). To overcome this problem, we impose a second, more flexible specification for $G$, using a discrete distribution with 4 points of supports. This flexible distribution allows for any type of correlation between $v_{e}$ and $v_{p}$. It is possible to show that the first specification is nested in the second one. In our empirical analysis, the second specification, with 4 points of support, has not been rejected. Moreover, our procedure, which follows Gaure et al. (2005), suggests that there is no reason to add more than four points of support to the heterogeneity distribution.

In the first specification, we assume that $v_{e}$ can take two different values $\mathrm{v}_{\mathrm{e} 1}$ et $\mathrm{v}_{\mathrm{e} 2}$, and that $v_{p}$ is defined as the product of $v_{e}$ and $\gamma$, a parameter to be estimated: $v_{p}=\gamma \cdot v_{e}$. As the results, the probabilities associated to the points of support can be defined as:

$$
\begin{aligned}
& P_{1}=\operatorname{Prob}\left(v_{e}=\mathrm{v}_{\mathrm{e} 1}, v_{p}=\gamma \cdot \mathrm{v}_{\mathrm{e} 1}\right) \\
& P_{2}=\operatorname{Prob}\left(v_{e}=\mathrm{v}_{\mathrm{e} 2}, v_{p}=\gamma \cdot \mathrm{v}_{\mathrm{e} 2}\right)
\end{aligned}
$$

We specify $P_{1}$ et $P_{2}$ using a Logit model:

$$
P_{1}=\frac{\exp \lambda}{1+\exp \lambda} \quad \text { and } \quad P_{2}=1-P_{1}=\frac{1}{1+\exp \lambda}
$$

In the second specification, with 4 points of support, we assume that $v_{m}(m=p, e)$ can take two different values $\mathrm{v}_{\mathrm{m} 1}$ et $\mathrm{v}_{\mathrm{m} 2}$. The four resulting probabilities are defined as follows:

$$
\begin{aligned}
& P_{11}=\operatorname{Prob}\left(v_{e}=\mathrm{v}_{\mathrm{e} 1}, v_{p}=\mathrm{v}_{\mathrm{p} 1}\right)=p_{1} \\
& P_{12}=\operatorname{Prob}\left(v_{e}=\mathrm{v}_{\mathrm{e} 1}, v_{p}=\mathrm{v}_{\mathrm{p} 2}\right)=p_{2} \\
& P_{21}=\operatorname{Prob}\left(v_{e}=\mathrm{v}_{\mathrm{e} 2}, v_{p}=\mathrm{v}_{\mathrm{p} 1}\right)=p_{3} \\
& P_{22}=\operatorname{Prob}\left(v_{e}=\mathrm{v}_{\mathrm{e} 2}, v_{p}=\mathrm{v}_{\mathrm{p} 2}\right)=p_{4}
\end{aligned}
$$

Probabilities $p_{1}$ to $p_{4}$ are specified using a multinomial Logit model:

$$
p_{j}=\frac{\exp \lambda_{j}}{1+\sum_{i=1}^{3} \exp \lambda_{i}} \operatorname{pour} j=1, \ldots, 3 \quad \text { and } \quad p_{4}=1-\sum_{j=1}^{3} p_{j}=\frac{1}{1+\sum_{i=1}^{3} \exp \lambda_{i}}
$$

\section{Results}

Our estimation results are presented in details in Table 2, which was separated in three parts in order to make reading easier: Table 2.a concerns transitions to full-time (regular) employment, Table 2.b concerns transitions to subsidised employment (AGR policy), and Table 2.c gives goodness-of-fit statistics as well as information on the unobserved heterogeneity distribution. Each table compares three different sets of results: without control for unobserved heterogeneity, with the one-factor loading heterogeneity distribution, and with the flexible heterogeneity distribution. For each set of results we give the estimated coefficients, exponential of the estimated coefficient, standard deviation, and p-value. For the sake of concision, we only comment our main results, and in particular the impact of AGR on the transition to regular employment, as well as the influence of unobserved heterogeneity. 


\section{TABLES 2.a, 2.b, 2.c ABOUT HERE}

In the model without heterogeneity, going through the AGR policy significantly increases the rate of transition (hazard) to regular employment: the estimated coefficient is equal to 0.73 , which corresponds to a hazard twice as high as in the control group (the multiplier of the hazard function is given by $\exp (0.73)=2.08$ ). However, this significant effect disappears as soon as we introduce a control for unobserved heterogeneity in the model: the effect of the AGR is insignificant in the model with a one-factor loading distribution, as well as in the model with a discrete distribution with 4 points of support.

Although each model presents the same Akaike Information Criterion (AIC $=2.83$ ), the models incorporating a control for unobserved heterogeneity seem to have a higher explanatory power. Introducing a discrete distribution with 4 points of support, though, does not increase the value of the likelihood. A distribution with 2 points of support therefore seems sufficient to capture the selection on unobservables.

The estimation suggests that AGR recipients have unobserved characteristics, which would have enhanced their transition to regular employment, even in the absence of this income-support policy. Considering these unobserved elements is crucial: once they are controlled for, the effect of the AGR is no longer significant. These observations are consistent with the idea, often mentioned in the literature, that wages for low-skilled workers increase very slowly, and with the fact that the $100 \%$ implicit marginal rate of withdrawal of the subsidy makes such increases even slower and unlikely (cf. Sections 1 and 2).

Nevertheless, the existence of unobserved elements playing in favour of the transition to regular employment, and the fact that the parameter associated to AGR remains positive in the models with heterogeneity suggest that accepting a part-time job sends a positive signal to employers. Thus, accepting to enter subsidised part-time employment seems to signal motivation and willingness to work, rather than adverse selection. We therefore anticipate that the recent reform of the AGR policy, in which the implicit marginal withdrawal rate of the subsidy is reduced, will reinforce this positive effect. This is matter for future research.

Secondary results bring to light determinants of the transition to unemployment that are often quoted in the literature: nationality, education level, and location. In all model specifications, non-Belgian women have a significantly lower transition rate to full-time employment. Additionally, women who originate from non-EU countries also have a lower transition rate to subsidised employment (i.e. they are also less likely to access AGR). Women who have less (more) than 12-14 years of schooling are less (more) likely to experience a transition to regular employment. More educated women are more likely to enter subsidised employment than less educated (according to the models with heterogeneity).

The regional variable displays disparities between Flanders on the one hand, and the Walloon region and Brussels on the other. Regional location does not influence the transition to subsidised employment; however, it affects the transition to regular employment. Thus, young Flemish women have a significantly higher transition rate to regular employment ( $+35 \%$ to $+45 \%$, depending on the model). 


\section{Conclusion}

In this paper, we evaluated the effect of an income-support policy (known as AGR) for unemployed persons accepting to work part-time. The analysis was performed on a sample of 8630 long-term unemployed young women without prior labour market experience. On the basis of the "timing of events method", we estimated the impact of accepting such a subsidised part-time job on the transition to full-time employment. The econometric model allows to control for selection on both observables and unobservables.

Our estimation results suggest that AGR recipients have unobserved characteristics that would have favoured their transition to full-time employment, even in the absence of an income support. Controlling for these unobserved characteristics is fundamental: as soon as one does this, the coefficient associated to AGR becomes insignificant. This observation is consistent with the finding that wages for low-skill workers increase very slowly, and with the possibility that the $100 \%$ implicit marginal withdrawal rate of the AGR makes wages progression even slower. On the other hand, the fact that unobserved characteristics accelerate the transition to regular employment, and that the effect of the AGR remains positive even when insignificant, suggests that programme participants send employers a positive signal (motivation, willingness to work, etc.). We therefore expect the recent reform of the AGR policy, in which the implicit marginal withdrawal rate of the subsidy is reduced, to reinforce this positive effect. This is matter for future research.

\section{References}

Abbring, J. H. and van den Berg, G. J. (2004), "Analyzing the Effect of Dynamically Assigned Treatments Using Duration Models, Binary Treatment Models, and Panel Data Models", Empirical Economics, 29(1), 5-20.

Abbring, J. H. and van den Berg, G. J. (2003), "The Nonparametric Identification of Treatment Effects in Duration Models", Econometrica, 71, 1491-1517.

Autor, D.H. and S.N. Houseman (2005), "Do Temporary Help Jobs Improve Labor Market Outcomes for Low-Skilled Workers? Evidence from Random Assignments", Uppjohn Institute Staff Working Paper, $\mathrm{n}^{\circ}$ 05-124, Kalamazoo: Uppjohn Institute.

Blank, R. M. (1998), "Labor Market Dynamics and Part-time Work", Research in Labor Economics, Polachek, Solomom, ed., Greenwich, Vol.17, pp.57-93, CT: JAI Press.

Blundell and Hoynes (2003), "Has "In-Work" Benefit Reform Helped the Labor Market?", in Card, D., Blundell, R. and R. B. Freeman (eds.), Seeking a Premier Economy: The Economic Effects of British Economic Reforms, 1980-2000, Chicago: The University of Chicago Press.

Bonnal, L., D. Fougère and A. Sérandon (1994), "L'impact des dispositifs d'emploi sur le devenir des jeunes chômeurs : une évaluation économétrique sur données longitudinales", Economie et Prévision, $\mathrm{n}^{\circ}$ 115, 1-28.

Bonnal, L., D. Fougère and A. Sérandon (1997), "Evaluation the Impact of French Employment Policies on Individual Labour Market Histories", Review of Economic Studies, 64, 683-713. 
Booth, A.L., M. Francesconi and J. Frank (2002), “Temporary Jobs: stepping-stones or dead ends?", The Economic Journal, 112 , 189-215.

Cahuc, P. (2002), “A quoi sert la prime pour l'emploi ?”, Revue française d'Economie, vol. $16,3-61$.

Calmfors, L. (1994), “Active Labor Market Policy and Unemployment - A Framework for the Analysis of Crucial Design Features" OECD Economic Studies, 22.

Card, D. and D. R. Hyslop (2005), "Estimating the Effects of a Time-Limited Earnings subsidy for Welfare-Leavers", Econometrica, 73(6), 1723-1770.

Card D. and Ph. K. Robins (1999), "Measuring "Wage Progression" Among Former Welfare Recipients", Center for Labor Economics, Discussion Paper, Berkeley.

D'Addio, A. and M . Rosholm (2005), "Exits from temporary jobs in Europe: A competing Risks analysis", Labour Economics, 12, 449-468.

De Greef I. (2000), "Les pièges financiers en Belgique : Aperçu de la législation du chômage, des spécificités institutionnelles et études de cas types", Revue Belge de Sécurité Sociale, 42 (2), pp. 265-327.

Dustmann, C. and C. Meghir (2005), "Wages, Experience and Seniority", Review of Economic Studies, 72, 77-108.

Eissa, N. and H. Hoynes (2005), "Behavioral Responses to Taxes : Lessons from the EITC and Labor Supply”, NBER working paper, $\mathrm{n}^{\circ} 11729$.

Farber, H.S. (1999) "Alternative and Part-Time Employment Arrangements as a Response to Job Loss", Journal of Labor Economics, Part 2, 17(4), S142-S169

Francesconi M. and W. Van der Klaauw (2004), “The Consequences of 'In-Work' Benefit Reform in Britain: New Evidence from Panel Data", IZA Discussion Paper Series, No. 1248, Bonn: IZA.

Gagliarducci, S. (2005), “The Dynamics of Repeated Temporary Jobs”, Labour Economics, $12,429-448$.

Gaure, S., K. Roed and T. Zhang (2005), "Time and Causality: A Monte Carlo Assessment of the Timing-of-Events Approach", Memorandum, $\mathrm{n}^{\circ}$ 19-2005, Oslo: Department of Economics, University of Oslo.

Gerfin, M., M. Lechner M. and H. Steiger (2002), "Does Subsidised Temporary Employment Get the Unemployed Back to Work? An Econometric Analysis of Two Different Schemes", IZA Discussion Paper, ${ }^{\circ}$ 606, Bonn: IZA.

Gladden, T. and C. Taber (2000), "Wage Progression among Less Skilled Workers" in D. Card and R. M. Blank (eds.) Finding Jobs: Work and Welfare Reform, New York: Russell Sage Foundation. 
Granier and Joutard (1999), "L'activité réduite favorise-t-elle la sortie du chômage ?", Economie et Statistique, № 321-322 (1/2), 133-148.

Grogger, J. (2005), "Welfare Reform, Returns to Experience, and Wages: Using Reservation Wages to Account for Selection Bias", NBER Working paper, N11621.

Heckman, J. and Singer, B. (1984), “A Method for Minimizing the Impact of Distributional Assumptions in Econometric Models for Duration Data", Econometrica, 52, 271-320.

Kvasnicka, M. (2005), "Does Temporary Agency Work Provide a Stepping Stone to Regular Employment?”, SFB 649 Discussion Paper, n 2005-31, Berlin: Humboldt University.

Larssen, L., L. Lindqvist and O. Nordström Skans (2005), "Stepping-Stones or Dead-Ends : an Analysis of Swedish Replacement Contracts", IFAU working paper, ${ }^{\circ}{ }^{2005-18, ~ U p p s a l a ~: ~}$ IFAU.

Lindsay, B. G. (1983), “The Geometry of Mixture Likelihoods: A General Theory”, The Annals of Statistics, Vol. 11, 86-94.

Ma, C.A., and A. Weiss (1993), "A Signalling Theory of Unemployment", European Economic Review, 37, 135-157.

McCormick, B. (1990), "A Theory of Signalling during Job Search, Employment, Efficiency, and "Stigmatised" Jobs", Review of Economic Studies, 57, 299-313.

Mc Call (1996), "Unemployment Insurance Rules, Joblessness, and Part-Time Work", Econometrica, 64, 647-682.

Mc Call (1997), "The Determinants of Full-time versus Part-time Reemployment following Displacement", Journal of Labor Economics, 15 (4), 714-734.

Meghir C. and E. Whitehouse (1996), "The Evolution of Wages in the UK: Evidence from Micro Data ", The Journal of Labor Economics, 14(1), 1-25.

Meyer, B. D. (1995), "Lessons from the U.S. Unemployment Insurance Experiments", Journal of Economic Literature, 33, 91-131.

Van den Berg G. (2001), "Duration models : specification, identification, and multiple durations", in J.J. Heckman and E. Leamer (eds.), Handbook of Econometrics, Volume V, Amsterdam : North-Holland.

Van Ours, J. C. (2004), "The locking-in effect of subsidized jobs", Journal of Comparative Economics, 32/1, 37-52.

Zijl, M., G. Van den Berg, and A. Heyma (2004), "Stepping Stones for the Unemployed: The Effect of Temporary Jobs on the Duration until Regular Work", IZA discussion paper, $\mathrm{n}^{\circ}$ 1241, Bonn: IZA. 
Table 1 - summary statistics ${ }^{15}$

\begin{tabular}{|c|c|c|c|c|}
\hline \multirow[t]{2}{*}{ VARIABLES } & \multicolumn{3}{|c|}{ sub-groups } & \multirow[b]{2}{*}{ TOTAL } \\
\hline & $\begin{array}{l}\text { Full employment } \\
\text { (control group) }\end{array}$ & $\begin{array}{c}\text { AGR } \\
\text { (treated) }\end{array}$ & Censored group & \\
\hline Age in years at the end of 1997 & $20.75(2.02)$ & $20.42(2.03)$ & $20.14(1.90)$ & $20.39(1.98)$ \\
\hline \multicolumn{5}{|l|}{ Nationality : } \\
\hline Belgian & 0.911 & 0.920 & 0.853 & 0.877 \\
\hline Non-Belgian EU & 0.048 & 0.0457 & 0.059 & 0.055 \\
\hline Non EU & 0.041 & 0.0343 & 0.088 & 0.068 \\
\hline \multicolumn{5}{|l|}{ Education level: } \\
\hline Primary (6 to 9 years schooling) & 0.039 & 0.074 & 0.107 & 0.079 \\
\hline Lower secondary (9 to 12 years) & 0.139 & 0.234 & 0.281 & 0.223 \\
\hline $\begin{array}{l}\text { Higher secondary (12 to } 14 \\
\text { years of schooling) }\end{array}$ & 0.495 & 0.457 & 0.469 & 0.479 \\
\hline $\begin{array}{l}\text { Higher education, non-university } \\
\text { (14 years of schooling and more) }\end{array}$ & 0.187 & 0.160 & 0.080 & 0.124 \\
\hline $\begin{array}{l}\text { University (16 years of schooling } \\
\text { and more) }\end{array}$ & 0.075 & 0.069 & 0.033 & 0.050 \\
\hline Other & 0.005 & 0.006 & 0.010 & 0.008 \\
\hline Unknown & 0.060 & 0 & 0.021 & 0.036 \\
\hline \multicolumn{5}{|l|}{ Relation to head of household: } \\
\hline Head & 0.066 & 0.177 & 0.114 & 0.096 \\
\hline Spouse & 0.033 & 0.051 & 0.070 & 0.055 \\
\hline Child & 0.802 & 0.640 & 0.674 & 0.724 \\
\hline Other & 0.018 & 0.040 & 0.026 & 0.023 \\
\hline No family relationship & 0.081 & 0.091 & 0.115 & 0.101 \\
\hline \multicolumn{5}{|l|}{ \# persons in household: } \\
\hline \# of persons, [0-1) year-old & 0.030 & 0.091 & 0.079 & 0.060 \\
\hline \# of persons, [1-3) year-old & 0.024 & 0.034 & 0.063 & 0.047 \\
\hline \# of persons, [3-6) year-old & 0.037 & 0.017 & 0.055 & 0.047 \\
\hline \# of persons, [6-12) year-old & 0.112 & 0.069 & 0.140 & 0.128 \\
\hline \# of persons, $[12-18)$ year-old & 0.250 & 0.211 & 0.272 & 0.262 \\
\hline \# of persons, [18-30) year-old & 0.488 & 0.377 & 0.484 & 0.483 \\
\hline \# of persons, [30-50) year-old & 0.630 & 0.446 & 0.569 & 0.591 \\
\hline \# of persons, [50-65) year-old & 0.368 & 0.297 & 0.295 & 0.324 \\
\hline \# of persons, [65-75) year-old & 0.033 & 0.046 & 0.036 & 0.035 \\
\hline \# of persons, $[75+)$ year-old & 0.019 & 0.034 & 0.014 & 0.016 \\
\hline Unemployment rate, end 1997 & $25.84(8.58)$ & $28.05(8.12)$ & $27.64(8.17)$ & $26.93(8.38)$ \\
\hline \multicolumn{5}{|l|}{ Region : } \\
\hline Walloon region & 0.303 & 0.200 & 0.207 & 0.245 \\
\hline Flanders & 0.598 & 0.680 & 0.666 & 0.639 \\
\hline Brussels & 0.098 & 0.120 & 0.127 & 0.116 \\
\hline Number of observations & 3.458 & 175 & 4.997 & 8.630 \\
\hline
\end{tabular}

Columns: average value

In brackets: standard deviation

\footnotetext{
${ }^{15}$ The month of entry in unemployment is not presented here; this information is available upon request from the authors.
} 
Table 2a - duration model estimates: transition to regular employment

\begin{tabular}{|c|c|c|c|c|c|c|c|c|c|c|c|c|}
\hline \multirow[t]{2}{*}{ VARIABLES } & \multicolumn{4}{|c|}{ No heterogeneity } & \multicolumn{4}{|c|}{ Heterogeneity : 2 pts of support } & \multicolumn{4}{|c|}{ heterogeneity: 4 pts of support } \\
\hline & $\beta$ & $\operatorname{Exp} \beta$ & $\sigma$ & $p$-val. & $\beta$ & $E x p \beta$ & $\sigma$ & $p$-val. & $\beta$ & $E x p \beta$ & $\sigma$ & $p$-val. \\
\hline Constant & -2.57 & 0.08 & 0.13 & 0.00 & & & & & & & & \\
\hline Age in 1997 & 0.01 & 1.01 & 0.01 & 0.32 & 0.01 & 1.01 & 0.01 & 0.30 & 0.01 & 1.01 & 0.01 & 0.28 \\
\hline \multicolumn{13}{|l|}{ Nationality: } \\
\hline \multicolumn{13}{|l|}{ Belgian (reference) } \\
\hline Non-Belgian EU & -0.15 & 0.86 & 0.08 & 0.03 & -0.16 & 0.85 & 0.09 & 0.03 & -0.17 & 0.85 & 0.09 & 0.03 \\
\hline Non EU & -0.64 & 0.53 & 0.09 & 0.00 & -0.71 & 0.49 & 0.10 & 0.00 & -0.72 & 0.49 & 0.10 & 0.00 \\
\hline \multicolumn{13}{|l|}{ Education level: } \\
\hline Primary & -0.88 & 0.41 & 0.09 & 0.00 & -0.96 & 0.38 & 0.10 & 0.00 & -0.97 & 0.38 & 0.10 & 0.00 \\
\hline $\begin{array}{l}\text { Lower secondary } \\
\text { Higher second. (ref.) }\end{array}$ & -0.60 & 0.55 & 0.05 & 0.00 & -0.65 & 0.52 & 0.06 & 0.00 & -0.65 & 0.52 & 0.06 & 0.00 \\
\hline Higher, non-university & 0.71 & 2.04 & 0.05 & 0.00 & 0.80 & 2.24 & 0.06 & 0.00 & 0.81 & 2.25 & 0.06 & 0.00 \\
\hline University & 0.76 & 2.13 & 0.07 & 0.00 & 0.84 & 2.31 & 0.08 & 0.00 & 0.84 & 2.32 & 0.09 & 0.00 \\
\hline Other & -0.70 & 0.49 & 0.23 & 0.00 & -0.75 & 0.47 & 0.26 & 0.00 & -0.75 & 0.47 & 0.25 & 0.00 \\
\hline Unknown & 0.95 & 2.59 & 0.08 & 0.00 & 1.00 & 2.73 & 0.09 & 0.00 & 1.01 & 2.76 & 0.10 & 0.00 \\
\hline \multicolumn{13}{|l|}{ Month of entry: } \\
\hline January & 0.13 & 1.14 & 0.14 & 0.16 & 0.13 & 1.14 & 0.14 & 0.17 & 0.13 & 1.14 & 0.15 & 0.20 \\
\hline February & -0.13 & 0.88 & 0.15 & 0.20 & -0.14 & 0.87 & 0.16 & 0.19 & -0.14 & 0.87 & 0.17 & 0.20 \\
\hline March & 0.13 & 1.13 & 0.10 & 0.11 & 0.14 & 1.15 & 0.12 & 0.12 & 0.14 & 1.15 & 0.11 & 0.11 \\
\hline May & 0.08 & 1.09 & 0.06 & 0.06 & 0.09 & 1.10 & 0.06 & 0.05 & 0.09 & 1.10 & 0.06 & 0.07 \\
\hline June & 0.07 & 1.07 & 0.04 & 0.06 & 0.08 & 1.08 & 0.05 & 0.05 & 0.08 & 1.08 & 0.05 & 0.06 \\
\hline July & -0.14 & 0.87 & 0.07 & 0.03 & -0.15 & 0.86 & 0.07 & 0.02 & -0.16 & 0.86 & 0.08 & 0.03 \\
\hline August & -0.27 & 0.76 & 0.10 & 0.00 & -0.29 & 0.75 & 0.11 & 0.00 & -0.29 & 0.75 & 0.11 & 0.00 \\
\hline September & -0.19 & 0.83 & 0.11 & 0.04 & -0.20 & 0.82 & 0.12 & 0.05 & -0.21 & 0.81 & 0.12 & 0.04 \\
\hline October & -0.18 & 0.83 & 0.12 & 0.07 & -0.20 & 0.82 & 0.13 & 0.06 & -0.20 & 0.82 & 0.13 & 0.06 \\
\hline November & -0.33 & 0.72 & 0.13 & 0.01 & -0.32 & 0.73 & 0.15 & 0.02 & -0.31 & 0.73 & 0.14 & 0.01 \\
\hline December & -0.16 & 0.85 & 0.14 & 0.12 & -0.17 & 0.84 & 0.14 & 0.12 & -0.17 & 0.84 & 0.15 & 0.12 \\
\hline April (reference) & & & & & & & & & & & & \\
\hline \multicolumn{13}{|l|}{ Relation to the head: } \\
\hline Head & -0.16 & 0.85 & 0.09 & 0.03 & -0.16 & 0.85 & 0.09 & 0.04 & -0.17 & 0.85 & 0.10 & 0.04 \\
\hline Spouse & -0.31 & 0.74 & 0.11 & 0.00 & -0.34 & 0.71 & 0.12 & 0.00 & -0.35 & 0.70 & 0.12 & 0.00 \\
\hline \multicolumn{13}{|l|}{ Child } \\
\hline Other & -0.17 & 0.85 & 0.14 & 0.12 & -0.18 & 0.83 & 0.15 & 0.11 & -0.19 & 0.83 & 0.15 & 0.11 \\
\hline No family relationship & -0.04 & 0.96 & 0.07 & 0.30 & -0.04 & 0.96 & 0.08 & 0.29 & -0.05 & 0.95 & 0.08 & 0.28 \\
\hline \# of persons: & & & & & & & & & & & & \\
\hline$\#$ of $[0-1)$ year-old & -053 & 50 & 007 & $0 \cap 0$ & -0.62 & 0.54 & 0.10 & 0.00 & -0.63 & 0.53 & 0.11 & 0.00 \\
\hline \# of [1-3) year-old & -0.53 & 0.59 & 0.07 & 0.00 & -0.50 & 0.61 & 0.11 & 0.00 & -0.50 & 0.60 & 0.12 & 0.00 \\
\hline \# of [3-6) year-old & 0.05 & 1.06 & 0.08 & 0.25 & 0.05 & 1.05 & 0.09 & 0.29 & 0.05 & 1.05 & 0.09 & 0.30 \\
\hline \# of [6-12) year-old & 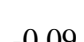 & 02 & ר 0 ? & $0 \cap 0$ & -0.08 & 0.92 & 0.04 & 0.03 & -0.08 & 0.92 & 0.05 & 0.04 \\
\hline \# of [12-18) year-old & -0.09 & 0.92 & 0.02 & 0.00 & -0.10 & 0.90 & 0.03 & 0.00 & -0.10 & 0.90 & 0.03 & 0.00 \\
\hline \# of [18-30) year-old & 0.00 & 1.00 & 0.02 & 0.48 & 0.00 & 1.00 & 0.03 & 0.48 & 0.00 & 1.00 & 0.03 & 0.48 \\
\hline$\#$ of $[30-50)$ year-old & 0.13 & 1.14 & 0.03 & 0.00 & 0.15 & 1.16 & 0.04 & 0.00 & 0.14 & 1.16 & 0.04 & 0.00 \\
\hline \# of [50-65) year-old & 0.05 & 1.05 & 0.04 & 0.09 & 0.05 & 1.05 & 0.04 & 0.09 & 0.05 & 1.05 & 0.04 & 0.11 \\
\hline \# of [65-75) year-old & -0.10 & 0.91 & 0.09 & 0.12 & -0.10 & 0.90 & 0.09 & 0.13 & -0.10 & 0.90 & 0.10 & 0.15 \\
\hline \# of [75+) year-old & 0.18 & 1.20 & 0.12 & 0.06 & 0.21 & 1.23 & 0.13 & 0.05 & 0.21 & 1.24 & 0.13 & 0.05 \\
\hline Unemp. rate, end 97 & -0.02 & 0.98 & 0.00 & 0.00 & -0.01 & 0.99 & 0.02 & 0.34 & -0.03 & 0.97 & 0.00 & 0.00 \\
\hline $\begin{array}{l}\Delta \text { unemployment rate } \\
\text { Region: }\end{array}$ & -0.02 & 0.98 & 0.01 & 0.01 & -0.02 & 0.98 & 0.01 & 0.02 & -0.02 & 0.98 & 0.01 & 0.01 \\
\hline$\overline{\text { Walloon region (ref.) }}$ & & & & & & & & & & & & \\
\hline Flanders & 0.30 & 1.35 & 0.07 & 0.00 & 0.36 & 1.44 & 0.07 & 0.00 & 0.36 & 1.43 & 0.08 & 0.00 \\
\hline Brussels & 0.09 & 1.09 & 0.07 & 0.09 & 0.11 & 1.11 & 0.07 & 0.06 & 0.11 & 1.11 & 0.07 & 0.07 \\
\hline Baseline : $2^{\text {nd }}$ quarter & -0.15 & 0.86 & 0.06 & 0.00 & -0.07 & 0.93 & 0.06 & 0.13 & -0.06 & 0.94 & 0.06 & 0.17 \\
\hline $3^{\text {rd }}$ quarter & -0.31 & 0.73 & 0.07 & 0.00 & -0.18 & 0.83 & 0.07 & 0.01 & -0.17 & 0.84 & 0.08 & 0.02 \\
\hline $4^{\text {th }}$ quarter & -0.33 & 0.72 & 0.07 & 0.00 & -0.17 & 0.85 & 0.08 & 0.02 & -0.15 & 0.86 & 0.09 & 0.06 \\
\hline $5^{\text {th }}$ quarter & -0.38 & 0.69 & 0.08 & 0.00 & -0.18 & 0.84 & 0.09 & 0.03 & -0.16 & 0.85 & 0.11 & 0.07 \\
\hline $6^{\text {th }}$ quarter & -0.48 & 0.62 & 0.09 & 0.00 & -0.25 & 0.78 & 0.11 & 0.01 & -0.23 & 0.80 & 0.12 & 0.03 \\
\hline $7^{\text {th }}$ quarter & -0.59 & 0.55 & 0.11 & 0.00 & -0.34 & 0.71 & 0.12 & 0.00 & -0.31 & 0.73 & 0.13 & 0.01 \\
\hline $8^{\text {th }}$ quarter & -0.72 & 0.49 & 0.12 & 0.00 & -0.44 & 0.64 & 0.14 & 0.00 & -0.42 & 0.66 & 0.15 & 0.00 \\
\hline $9^{\text {th }}$ quarter & -0.81 & 0.44 & 0.14 & 0.00 & -0.52 & 0.59 & 0.15 & 0.00 & -0.49 & 0.61 & 0.17 & 0.00 \\
\hline $10^{\text {th }} \mathrm{q}$ & -0.93 & 0.39 & 0.17 & 0.00 & -0.62 & 0.54 & 0.17 & 0.00 & -0.59 & 0.55 & 0.19 & 0.00 \\
\hline $11^{\text {th }} \mathrm{q}$. & -0.76 & 0.47 & 0.16 & 0.00 & -0.44 & 0.64 & 0.17 & 0.00 & -0.41 & 0.66 & 0.18 & 0.01 \\
\hline $12^{\text {th }} \mathrm{q}$. & -1.52 & 0.22 & 0.27 & 0.00 & -1.20 & 0.30 & 0.28 & 0.00 & -1.16 & 0.31 & 0.28 & 0.00 \\
\hline $13^{\text {th }} \mathrm{q}$. & -1.29 & 0.28 & 0.24 & 0.00 & -0.95 & 0.39 & 0.24 & 0.00 & -0.92 & 0.40 & 0.27 & 0.00 \\
\hline $14^{\text {th }} \mathrm{q}$. & -1.77 & 0.17 & 0.33 & 0.00 & -1.42 & 0.24 & 0.34 & 0.00 & -1.39 & 0.25 & 0.35 & 0.00 \\
\hline $15^{\text {th }} \mathrm{q}$. & -2.60 & 0.07 & 0.64 & 0.00 & -2.24 & 0.11 & 0.70 & 0.00 & -2.21 & 0.11 & 0.66 & 0.00 \\
\hline Effect of AGR ( $\delta$ ) & 0.73 & 2.08 & 0.12 & 0.00 & 0.12 & 1.13 & 0.34 & 0.36 & 0.17 & 1.19 & 0.31 & 0.29 \\
\hline
\end{tabular}


Tableau 2b - duration model estimates: transition to ALMP

\begin{tabular}{|c|c|c|c|c|c|c|c|c|c|c|c|c|}
\hline \multirow[t]{2}{*}{ VARIABLES } & \multicolumn{4}{|c|}{ No heterogeneity } & \multicolumn{4}{|c|}{ Heterogeneity : 2 pts of support } & \multicolumn{4}{|c|}{ heterogeneity: 4 pts of support } \\
\hline & $\beta$ & $\operatorname{Exp} \beta$ & $\sigma$ & $p$-val. & $\beta$ & $E x p \beta$ & $\sigma$ & $p$-val. & $\beta$ & $E x p \beta$ & $\sigma$ & $p$-val \\
\hline Constant & -5.80 & 0.00 & 0.68 & 0.00 & & & & & & & & \\
\hline Age in 1997 & -0.08 & 0.92 & 0.06 & 0.08 & -0.08 & 0.92 & 0.05 & 0.05 & -0.08 & 0.92 & 0.06 & 0.10 \\
\hline \multicolumn{13}{|l|}{ Nationality: } \\
\hline \multicolumn{13}{|l|}{ Belgian (reference) } \\
\hline Non-Belgian EU & -0.24 & 0.79 & 0.40 & 0.28 & -0.26 & 0.77 & 0.38 & 0.24 & -0.26 & 0.77 & 0.42 & 0.27 \\
\hline Non EU & -0.93 & 0.40 & 0.45 & 0.02 & -1.08 & 0.34 & 0.44 & 0.01 & -1.07 & 0.34 & 0.47 & 0.01 \\
\hline \multicolumn{13}{|l|}{ Education level: } \\
\hline Primary & -0.57 & 0.56 & 0.34 & 0.05 & -0.71 & 0.49 & 0.33 & 0.02 & -0.69 & 0.50 & 0.36 & 0.03 \\
\hline $\begin{array}{l}\text { Lower secondary } \\
\text { Higher second. (ref.) }\end{array}$ & -0.28 & 0.75 & 0.21 & 0.09 & -0.39 & 0.68 & 0.22 & 0.04 & -0.38 & 0.69 & 0.23 & 0.05 \\
\hline Higher, non-university & 0.93 & 2.53 & 0.28 & 0.00 & 1.12 & 3.07 & 0.26 & 0.00 & 1.11 & 3.03 & 0.31 & 0.00 \\
\hline University & 1.28 & 3.59 & 0.39 & 0.00 & 1.43 & 4.18 & 0.38 & 0.00 & 1.41 & 4.10 & 0.41 & 0.00 \\
\hline Other or unknown & -1.36 & 0.26 & 1.23 & 0.13 & -1.38 & 0.25 & 0.96 & 0.07 & -1.42 & 0.24 & 1.25 & 0.13 \\
\hline \multicolumn{13}{|l|}{ Month of entry: } \\
\hline January & 0.09 & 1.09 & 0.54 & 0.44 & 0.12 & 1.13 & 0.51 & 0.41 & 0.10 & 1.11 & 0.57 & 0.43 \\
\hline February & -0.77 & 0.46 & 0.79 & 0.17 & -0.77 & 0.46 & 0.93 & 0.20 & -0.77 & 0.46 & 0.81 & 0.17 \\
\hline March & -0.63 & 0.53 & 0.63 & 0.16 & -0.61 & 0.54 & 0.69 & 0.19 & -0.60 & 0.55 & 0.68 & 0.19 \\
\hline May & 0.09 & 1.10 & 0.26 & 0.36 & 0.08 & 1.08 & 0.26 & 0.38 & 0.09 & 1.09 & 0.27 & 0.37 \\
\hline June & -0.47 & 0.63 & 0.24 & 0.03 & -0.44 & 0.64 & 0.23 & 0.03 & -0.44 & 0.65 & 0.25 & 0.04 \\
\hline July & 0.26 & 1.29 & 0.27 & 0.17 & 0.21 & 1.23 & 0.27 & 0.22 & 0.22 & 1.24 & 0.29 & 0.22 \\
\hline August & -1.17 & 0.31 & 0.62 & 0.03 & -1.23 & 0.29 & 0.61 & 0.02 & -1.22 & 0.30 & 0.66 & 0.03 \\
\hline September & -0.09 & 0.91 & 0.45 & 0.42 & -0.11 & 0.90 & 0.46 & 0.41 & -0.11 & 0.90 & 0.48 & 0.41 \\
\hline October & 0.48 & 1.62 & 0.39 & 0.11 & 0.47 & 1.60 & 0.39 & 0.12 & 0.48 & 1.61 & 0.44 & 0.14 \\
\hline November & -0.13 & 0.88 & 0.59 & 0.41 & -0.20 & 0.82 & 0.57 & 0.36 & -0.19 & 0.83 & 0.60 & 0.38 \\
\hline $\begin{array}{l}\text { December } \\
\text { April (reference) }\end{array}$ & -0.13 & 0.88 & 0.56 & 0.41 & -0.15 & 0.86 & 0.59 & 0.40 & -0.14 & 0.87 & 0.57 & 0.40 \\
\hline \multicolumn{13}{|l|}{ Relation to the head: } \\
\hline Head & -0.16 & 0.85 & 0.34 & 0.32 & -0.26 & 0.77 & 0.33 & 0.22 & -0.24 & 0.79 & 0.37 & 0.26 \\
\hline Spouse & -0.68 & 0.51 & 0.48 & 0.08 & -0.85 & 0.43 & 0.44 & 0.03 & -0.81 & 0.44 & 0.52 & 0.06 \\
\hline Child & & & & & & & & & & & & \\
\hline Other & 0.25 & 1.29 & 0.52 & 0.31 & 0.01 & 1.01 & 0.52 & 0.49 & 0.01 & 1.01 & 0.59 & 0.50 \\
\hline No family relationship & -0.57 & 0.56 & 0.35 & 0.05 & -0.65 & 0.52 & 0.35 & 0.03 & -0.63 & 0.53 & 0.39 & 0.05 \\
\hline \multicolumn{13}{|l|}{ \# of persons: } \\
\hline \# of [0-1) year-old & 0.23 & 1.26 & 0.31 & 0.22 & 0.13 & 1.14 & 0.27 & 0.32 & 0.13 & 1.14 & 0.34 & 0.35 \\
\hline \# of [1-3) year-old & & & & & -0.39 & 0.68 & 0.43 & 0.18 & -0.38 & 0.68 & 0.46 & 0.20 \\
\hline \# of [3-6) year-old & 0 & 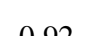 & 0 & ר 0 & -0.39 & 0.68 & 0.50 & 0.22 & -0.39 & 0.67 & 0.50 & 0.22 \\
\hline \# of [6-12) year-old & -0.08 & 0.92 & 0.10 & 0.22 & -0.30 & 0.74 & 0.25 & 0.11 & -0.31 & 0.74 & 0.26 & 0.12 \\
\hline$\#$ of $[12-18)$ year-old & & & & & 0.14 & 1.15 & 0.14 & 0.16 & 0.14 & 1.15 & 0.16 & 0.19 \\
\hline \# of [18-30) year-old & -0.13 & 0.88 & 0.13 & 0.15 & -0.14 & 0.87 & 0.12 & 0.12 & -0.14 & 0.87 & 0.13 & 0.15 \\
\hline$\#$ of $[30-50)$ year-old & & & & & -0.56 & 0.57 & 0.16 & 0.00 & -0.55 & 0.58 & 0.19 & 0.00 \\
\hline \# of [50-65) year-old & -0.43 & 0.65 & 0.17 & 0.01 & -0.45 & 0.64 & 0.17 & 0.00 & -0.43 & 0.65 & 0.21 & 0.02 \\
\hline \# of [65-75) year-old & & & & & -0.07 & 0.93 & 0.33 & 0.41 & -0.06 & 0.94 & 0.32 & 0.43 \\
\hline \# of [75+) year-old & 0.56 & 1.75 & 0.47 & 0.12 & 0.60 & 1.82 & 0.44 & 0.09 & 0.63 & 1.88 & 0.53 & 0.12 \\
\hline Unemp. rate, end 97 & 0.00 & 1.00 & 0.02 & 0.50 & -0.01 & 0.99 & 0.02 & 0.34 & -0.01 & 0.99 & 0.02 & 0.40 \\
\hline$\Delta$ unemployment rate & 0.02 & 1.02 & 0.04 & 0.29 & 0.02 & 1.02 & 0.03 & 0.30 & 0.02 & 1.02 & 0.04 & 0.33 \\
\hline \multirow{2}{*}{\multicolumn{13}{|c|}{$\frac{\text { Region : }}{\text { Walloon region (ref.) }}$}} \\
\hline & & & & & & & & & & & & \\
\hline Flanders & 0.44 & 1.56 & 0.38 & 0.13 & 0.49 & 1.63 & 0.35 & 0.08 & 0.50 & 1.65 & 0.40 & 0.11 \\
\hline Brussels & 0.23 & 1.25 & 0.31 & 0.23 & 0.24 & 1.27 & 0.28 & 0.20 & 0.24 & 1.27 & 0.32 & 0.23 \\
\hline \multirow{2}{*}{$\begin{array}{r}\text { Baseline: } \\
\text { 5-8 quart. } \\
\text { 9-15 quart. }\end{array}$} & 0.18 & 1.20 & 0.23 & 0.21 & 0.44 & 1.56 & 0.22 & 0.02 & 0.44 & 1.56 & 0.24 & 0.03 \\
\hline & 0.27 & 1.30 & 0.30 & 0.19 & 0.70 & 2.00 & 0.29 & 0.01 & 0.68 & 1.97 & 0.35 & 0.03 \\
\hline
\end{tabular}


Table 2c - duration model estimates: goodness-of-fit statistics and unobserved heterogeneity

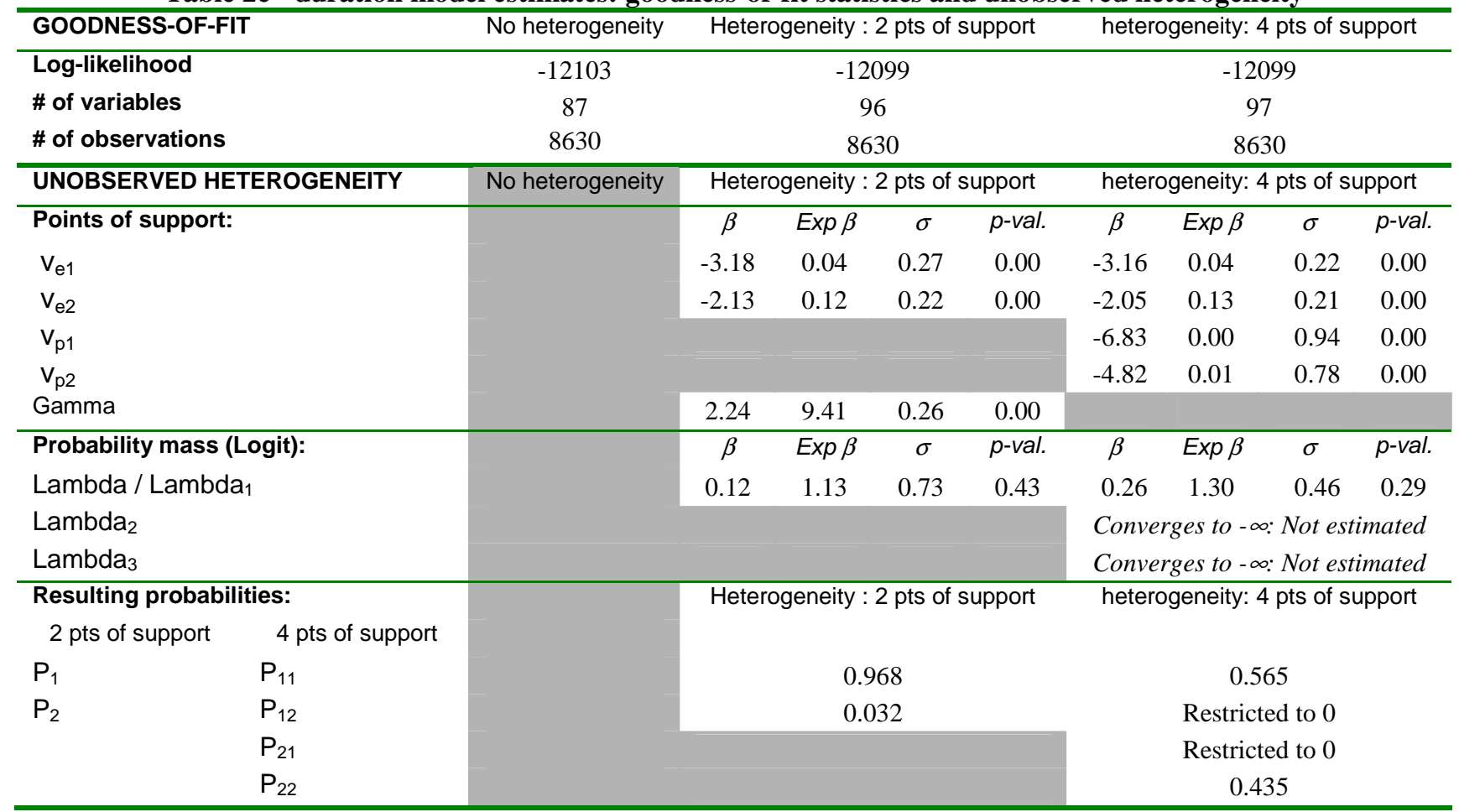

